the same as the one Miyake identified with $\mathrm{FeCr}_{2} \mathrm{O}_{4}$.

In interpreting the experimental results summarized above, it is natural to consider the oxide formed at lower temperatures as the naturally occurring film, which in the case of stainless steels has now been shown to be $\alpha-(\mathrm{Fe}, \mathrm{Cr})_{2} \mathrm{O}_{3}$.

I wish to express my thanks to Dr. Iitaka for his guidance and encouragement.

Institute of Physical and Chemical Research, Tokyo.

Feb. 5.

${ }^{1}$ Miyake, S., Sci. Pap. Inst. Phys. Chem. Res. Tokyo, 31, 161 (1937).

2 Thomson, G. P., Unpublished observation cited by Thomson and Cochrane in "Theory and Practice of Electr on Diffraction", 179 (London: Macmillan, 1939).

\section{Scandinavian Influence in Scottish Ethnology}

A FEW months ago ${ }^{t}$ we appealed to centres of the emergency blood transfusion service, and in particular to those which we were supplying with testing serum, to allow us to assemble the extensive data on blood group frequencies in Great Britain, then for the first time becoming available. We were confident that such a collection would throw light on the precision with which such extensive groupings can be relied on to determine the gene-ratios in our population, and we hoped further that this precision might be sufficient to detect with certainty any such small variations of ethnographic significance as might exist within our island.

In a preliminary survey, exhibited at the meeting (January 12, 1940) of the Pathological Society at Cambridge, it was shown that a consistent gradient in the frequency of the antigen $A$ is found as we pass from southern England to Scotland. Further data since accumulated bring our totals to 10,969 for Scotland and 8,716 for northern England, which show clearly intermediate frequencies. For southern England our compilation amounts to 106,477.

The values we present are not entirely unselected. A few returns have had to be set aside as apparently anomalous, and only in some cases has the cause of disturbance been ascertained. Systematic errors, not all of which are yet understood, do undoubtedly affect the frequency of the rarest of the four bloodgroups $(A B)$. As a further precaution, we have ealeulated the gene-ratios from the other three groups only, as in this way the effect of grouping errors is diminished.

The contrast between our three main areas, Scotland, England north of the Humber, and southern England, may be shown either in the relative frequencies of the four distinguishable phenotypes, or in those of the three allelomorphic genes:

TABLE 1

Phenotypic Frequencles

\begin{tabular}{lccccc} 
& \multicolumn{1}{c}{$O$} & $A$ & $B$ & $A B$ \\
Scotland . & $\ldots$ & $52 \cdot 019$ & $34 \cdot 233$ & $10 \cdot 429$ & $3 \cdot 318$ \\
N. Fngland & $\ldots$ & $48 \cdot 600$ & $40 \cdot 340$ & $8 \cdot 536$ & $2 \cdot 524$ \\
S. England & $\ldots$ & $45 \cdot 232$ & $43 \cdot 162$ & $8 \cdot 508$ & $3 \cdot 097$
\end{tabular}

The change in the ratio $A: O$ is not, apparently, influenced by the traditional and political Border, but is apparently continuous, and doubtless a cause of heterogeneity, too slight to be detected on the numbers yet available, within the three chosen regions. The corresponding gene-frequencies are as follows :

\begin{tabular}{lcccc}
\multicolumn{5}{c}{ Table 2 } \\
. Gene Frequencies \\
Scotland & $\ldots$ & $72 \cdot 247$ & $20 \cdot 783$ & $6 \cdot 970$ \\
N. Fngland & $\ldots$ & $69 \cdot 587$ & $24 \cdot 549$ & $5 \cdot 864$ \\
S. England & $\ldots$ & $67 \cdot 207$ & $26 \cdot 744$ & $6 \cdot 048$
\end{tabular}

as shown in the diagram below.

It has been customary for ethnologists to suppose that the northern inhabitants of Britain differ from their southern neighbours by reason of a greater infiltration of Scandinavian blood. The modern Scandinavians, however, differ from the English in having not a lower but a higher frequency of $A$. Thus if, setting aside the small fraction of these populations earrying the gene $B$, we compare the phenotypic ratios $A /(A+O)$, we find, using the best available series, Norway $58 \cdot 0$, Sweden $58 \cdot 6$, Denmark $50 \cdot 0$, against $S$. England 48.8, N. England $45 \cdot 4$, Scotland $39 \cdot 7$.

English contact with neighbouring Europe has been extensive since the Roman period; the values for Holland $48 \cdot 6$, Belgium $46 \cdot 6$, France $50 \cdot 1$, and Spain 53.4 are fully in accordance with the view that the English province has been influenced by settlement or intermixture with neighbouring Continental peoples. No Continental population, how. ever, in the north or in the south, comes near to the Scottish ratio.

$$
\text { O VIIIIIAVIIIIA B scotland }
$$

